Journal of Applied Pharmaceutical Science Vol. 5 (12), pp. 147-153, December, 2015

Available online at http://www.japsonline.com

DOI: $10.7324 / J A P S .2015 .501226$

ISSN 2231-3354 (cc) BY-NC-SA

\title{
Pilot Study of Quality of Diclofenac Generic Products Using Validated In-House Method: Indian Drug Regulatory Concern
}

\author{
Ahmed Nawaz Khan ${ }^{1 *}$, Roop Krishen $\mathrm{Khar}^{2}$, Malairaman Udayabanu ${ }^{1}$ \\ ${ }^{1}$ Department of Pharmacy, Jaypee University of Information Technology, Waknaghat, Solan-173234, India. \\ ${ }^{2}$ Department of Pharmaceutics, B.S. Anangpuria Institute of Pharmacy, Alampur Faridabad-121001, India.
}

\begin{tabular}{l} 
ARTICLE INFO \\
\hline Article history: \\
Received on: $21 / 09 / 2015$ \\
Revised on: $14 / 10 / 2015$ \\
Accepted on: 07/11/2015 \\
Available online: $27 / 12 / 2015$ \\
\hline Key words: \\
Diclofenac, Generic, \\
Substandard, Drug Quality, \\
Method Development, \\
Regulatory Affairs.
\end{tabular}

\begin{abstract}
Globally, the expanding issues over the extent of substandard or spurious medicines remain a challenge. It is operated largely by encompassing wrong therapeutic doses or adulterated formulations that necessitates routine monitoring to avoid any potential public health adversity. This study was aimed to determine the diclofenac sodium content in generic products available in northern Indian market. Therefore, 32 commercially available generic products of diclofenac sodium tablet were procured from the open market and subjected to assay evaluation using in-house developed and validated high performance liquid chromatography (HPLC) method. Product identification was confirmed by thin layer chromatography (TLC) method; and the quantitative results by validated in-house HPLC method showed $34.37 \%$ (11/32) products as out of Indian Pharmacopoeia specification including $15.62 \%$ (5/32) substandard products. This makes the health situation miserable for public and their trust. On comparing the assay with price of each tablet, it was noticed that quality of products was irrespective of price. People rely completely on manufacturer quality promises and on regulatory process. However, such substandard products which still exist in the market for use by the patient; unfortunately not identified yet, poses a serious issue and require some interventions to stop them in entering into market. So there is an urgent need to carry out the quality evaluation on regular and large scale by the state and national drug authorities to ensure better quality medicines.
\end{abstract}

\section{INTRODUCTION}

Globally more than 2 billion population is deprived of the essential medicines (WHO, 2007), this may be due to higher cost of the drugs (Grover and Citro, 2011) and low grade of medicines, which are considered as the prospective menace for the public health (International Medical Products AntiCounterfeiting Taskforce (IMPACT), 2008; Johnston and Holt, 2014). Markedly for developing nations it may have a compelling impact and lead to clinical loss along with the economical burden (Johnston and Holt, 2014; Newton, Green, and Fernández, 2010). Some of the complicating factors that affects the quality of the drug products are with regard to the quantity of active pharmaceutical ingredient (API) which mismatches with the label claim or occasionally no API, unwanted excipient and impurity content (Green, 2015; WHO).

\footnotetext{
* Corresponding Author

Email: ahmednawaz4u@gmail.com
}

Irrespective of the causes, poor quality affects the health in the same way which ultimately insignificant to the patient (Bate, 2012). Therefore, this global issue of substandard medication needs a comparative consideration as it influences a broad set of population. Drug products from the market undergo evaluation under routine check by the regulatory authorities. Their active pharmaceutical ingredient (API) may differ noticeably due to complex method of formulation and production but it must be within pharmacopoeia specification. Many studies showed the significant differences in the quality of products (Bate et al., 2009; Sheth et al., 2007). The incompetency in regulation to control the falsified and substandard drugs is leading to a severe impact on the health and economic ramifications in low and middle income countries (Cameron, Ewen, Ross-Degnan, Ball, and Laing, 2009). Consequently, availability of poor quality medicines diminishes the possibilities of fruitful treatment for individual patients which obstruct improved results all together (Suleman et al., 2014). Moreover, failing treatments and critical adverse effects including death are some of the major incidences from developing countries 
(Heyman and Williams, 2011; King and Kanavos, 2002) and it may be the result of inadequate medications related to spurious/falsely-labeled/falsified/counterfeit (SFFC) medicines (WHO, 2012). Assuredly, the complete list of undesirable effects and number of incidences due to substandard or spurious drug is still unknown.

Mainly low and middle-income countries have a weak pharmacovigilance and drug regulatory system (Cameron et al., 2009). Therefore as general public health disputes, the issue of the proximity of substandard and SFFC solutions for open utilization ought to draw watchful consideration, primarily for developing nations (Nsimba, 2008). A study suggests, 12-25\% of the medicines distributed globally from India are contaminated, substandard and counterfeit (PSM, 2013). However, within the Indian domestic market; the indigent quality of medicine is on a fall (Khan and Khar, 2015), whereas without any concrete scientific evidence the media reports 30-40\% magnitude (PSM, 2010). Evidently such situation makes the regulatory system miserable for the public health.

Substandard medications are most likely a bigger issue influencing more individuals, and therefore unquestionably need a comparative consideration. No study has been performed in the last few years and the real extent of the problem still remains ambiguous. Moreover, impractical pricing of medicines is further influencing to the crisis in the public health domain and may undermine efforts to improve healthcare (King and Kanavos, 2002). Worldwide awareness has been growing on the increasing incidence of substandard and spurious drug, whereas India is still lacking on the issue. Thus, to counteract the issue of spurious and substandard quality medicine in India there is an urgent need for additional research or routine analytical evidences to explain the magnitude of the problem.

Most often used medicines like amoxicillin, azithromycin, metformin (Martin, 2011) and diclofenac (McGettigan and Henry, 2013) etc. should be evaluated on priority. Thus we have selected diclofenac sodium (DICLO) tablet generic products. Diclofenac (2-[(2,6-dichlorophenyl)amino] benzeneacetic acid) is a nonsteroidal anti-inflammatory drug (NSAID) belongs to phenylacetic acid class. Irrespective of its 40$60 \%$ bioavailability and fatal gastrointestinal adverse effects like stomach or intestinal bleeding, ulceration, inflammation and perforation of stomach etc.; (Rostom et al., 2002; Silverstein et al., 2000) it is widely used for the symptomatic relief of pain and inflammation; and has favorable therapeutic effect in arthritis, musculoskeletal disorder, toothache and dysmenorrheal (Chan et al., 2004; Dugowson and Gnanashanmugam, 2006). It is a 'Scheduled H' drug under Drug and Cosmetic Act and Rules (Government of India, 2005) and also included in National List of Essential Medicines(NLEM) of India and globally the most widely prescribed NSAID (McGettigan and Henry, 2013). Based on the widely prescribed and some reported substandard quality of diclofenac (Drugscontrol.org, 2014) we aimed this pilot study to explore the quality of diclofenac generic products and to observe how the prices are associated with corresponding quality.

\section{MATERIAL AND METHOD}

\section{Material \\ Chemical and reagent}

Diclofenac sodium API and excipients for placebo were provided by the Ranbaxy (India). Certified reference material of diclofenac sodium was purchased from Sigma Aldrich. High performance liquid chromatography (HPLC) grade methanol (Lichrosolv), phosphoric acid (EMSURE), monobasic sodium phosphate GR grade were procured from Merck (India). Water used during analysis was purified through a Millipore Milli-Q (Waltham, MA, USA) water system.

\section{Instruments}

A HPLC (Waters, Milford, MA, USA) equipped with Alliance 2695 separations module and 2996 photodiode array detector was employed throughout the analysis using octadecylsilane bonded C-18 $(250 \mathrm{~mm} \times 46 \mathrm{~mm}, 5 \mu \mathrm{m})$ column (Waters). All samples were weighed using TB-215D (Denver Instrument, Germany) analytical balance. And chromatograms were processed using Empower Pro software (Waters).

\section{Method \\ Product identification}

For identification, thin layer chromatography was used in accordance to Indian pharmacopoeia (IP, 2010). For this, a precoated silica gel 60 F254 plate was spotted with $1 \mu \mathrm{L}$ of 10 $\mathrm{mg} / \mathrm{mL}$ concentration of DICLO reference standard (RS) and all market products. After air drying the plate was sprayed with a 0.5 percent $\mathrm{w} / \mathrm{v}$ solution of potassium dichromate in dilute sulfuric acid. Spots were visualized and identified corresponding to the retention factor value of DICLO-RS.

\section{Assay method development}

A new HPLC method was developed using reference of diclofenac sodium tablet monograph mentioned in United State Pharmacopoeia (USP29-NF24). DICLO-RS was used as a control. A blend of microcrystalline cellulose, talc, croscarmellose sodium, magnesium stearate and colloidal silicon dioxide was prepared and assumed as placebo.

In accordance with developed method, $0.01 \mathrm{M}$ phosphoric acid and $0.01 \mathrm{M}$ monobasic sodium phosphate (1:1) buffer was prepared as solvent mixture and adjusted to $\mathrm{pH}$ of $2.5 \pm 0.05$ using $5 \%$ phosphoric acid (v/v) and ultimately filtered through $0.20 \mu \mathrm{m}$ membrane nylon filter and degassed in ultrasonic bath. Mobile phase comprised of 70 volume of methanol and 30 volume of phosphate buffer, which was degassed through sonication and vacuumed prior to use. Diluent of methanol and water (70:30) was used in the preparation of analytical sample solutions. DICLO-RS solution of $0.2 \mathrm{mg} / \mathrm{mL}$ was used as system suitability solution. The analysis was carried out at $1.0 \mathrm{~mL}$ per min flow rate under isocratic mode for $15 \mathrm{~min}$ run time. The column was held at ambient temperature, the volume of injection was $10 \mu \mathrm{L}$. Peak area response was detected by extracting chromatogram at $254 \mathrm{~nm}$. Filter compatibility was done with one-use $0.45 \mu \mathrm{m}$ nylon filter 
and polytetrafluoroehtylene (PTFE) filter while supernatant of the centrifugate was used as control. Analytical stability of standard and sample in solvent at $25^{\circ} \mathrm{C}$ was done at $0,1,3,6,12,18$, and 24 hours. A solution of DICLO-RS spiked with two known impurity of diclofenac that is Impurity A (1-(2,6-dichlorophenyl)indolin-2one and Impurity E (indoline-2-one); were used as resolution solution to ensure specificity. Resolution, $\mathrm{R}$ between Impurity A and Impurity $\mathrm{E}$ was set at not less than 5 and between Impurity $\mathrm{A}$ and diclofenac not less than 2 as a peak resolution criterion. For assuring the correct result percent of relative standard deviation (RSD) of peak area response for replicate samples were posed not to be more than 2. A sample of standard spiked with placebo was also prepared to verify the system suitability with injection run time for 30 minutes.

\section{Assay method validation}

In accordance with the Q2(R1) International Conference on Harmonization ( $\mathrm{ICH})$ guidelines method was validated with recommended parameters which include specificity, linearity, accuracy, precision and robustness (ICH, 2005). Validation sample set were quantified against mean peak area of six injections. For system suitability criterion, peak tailing factor must be less than 2 , peak area $\%$ RSD of five injection of standard solution must be less than 2 and theoretical plates should not be less than 3000. The peak purity was determined based on lower purity angle than purity threshold of the main peak.

Specificity of method was shown by spiked samples and no peak was eluted with the main peak of API which further validated with spectra match plot. Method linearity was illustrated by the standard calibration curve of six samples in the range of about $0.14-0.26 \mathrm{mg} / \mathrm{mL}$ (that is $70 \%, 80 \%, 90 \%, 100 \%, 110 \%$ and $130 \%$ of the $0.2 \mathrm{mg} / \mathrm{mL}$ concentration). Accuracy and precision were established by assessing recovery and \%RSD values obtained with three test solutions, each at concentration of $0.14,0.20$, and $0.26 \mathrm{mg} / \mathrm{mL}$ corresponding to $70 \%, 100 \%$ and $130 \%$ of the API concentration. Recovery was estimated by comparing calculated theoretical concentration from the standard curve and the nominal concentration. Method robustness was demonstrated by changing in flow rate, column oven temperature, minor component and extracting wavelength. The robustness was tested with a 0.2 $\mathrm{mg} / \mathrm{mL}$ standard solution, and explained by the effect of parameter modification on peak theoretical plate count and tailing factor. Overall \% RSD for robustness was fixed not to be more than 2 and peak purity must pass.

\section{Generic Products collection}

Simple sampling process was done when one of the authors posed as customer and purchased 32 drug products directly without prescription from storefront wholesaler or retailer of open market located in urban and semi-urban areas of Northern India. There were 31 products of different companies and among them one product was in two batches. Thus in total 32 products of DICLO tablet were procured which were of $50 \mathrm{mg}$ dose except one with $100 \mathrm{mg}$ dose. Once procured all generic products were stored at ambient temperature with low humidity and no sunlight until assay evaluation.

\section{Assay of market product}

Ten tablet of each product were transferred in to $100 \mathrm{~mL}$ amber color volumetric flask. Initially half of the volume was made up with diluent and vigorously shaken mechanically for about 30 minutes till all tablets disintegrate. Some samples were not dissolved mechanically due to coating; therefore they were sonicated for 15 minutes. Thereafter volume was made up and a concentration of about $0.20 \mathrm{mg} / \mathrm{mL}$ of DICLO was obtained. Before injection, each sample was filtered with new disposable PTFE filter.

All 32 market products were assayed using aforementioned in house developed HPLC method in duplicate. Six injections of DICLO-RS of $0.20 \mathrm{mg} / \mathrm{mL}$ prepared in mobile phase were used to determine to fulfill the system suitability criterion. Against the peak area response of DICLO-RS; assay was determined from the percent label claim of API content in individual product. For calculating the precise assay result; \%RSD of two preparations was fixed not to be more than 2. For assay; to pass the pharmacopoeia specification each product must be within $89.3 \%-110.8 \%$ of the label claim. While in accordance to guidelines by Indian pharmaceuticals regulatory authority that is Central Drug Standard Control Organization (CDSCO), New Delhi, product which fails assay $5 \%$ below the pharmacopoeia specification that is below $84.3 \%$ are considered to be substandard product and not of standard quality(NSQ) (CDSCO, 2008). This minor change in the range was due to considering ten tablets of a product and to compensate the sampling error as mentioned in IP.

\section{RESULT AND DISCUSSION}

Ultra-violet spectroscopy recommended by IP was considered as primitive method and due to use of $100 \%$ methanol as diluents mentioned in diclofenac monograph; preliminary result were showed variations in the assay. Therefore, a new method of HPLC was developed and validated for the evaluation of the commercial generic DICLO products. However, for ensuring identity of DICLO, recommended TLC method was followed according to Indian pharmacopoeia. Figure 1 showed all products contain the claimed API.

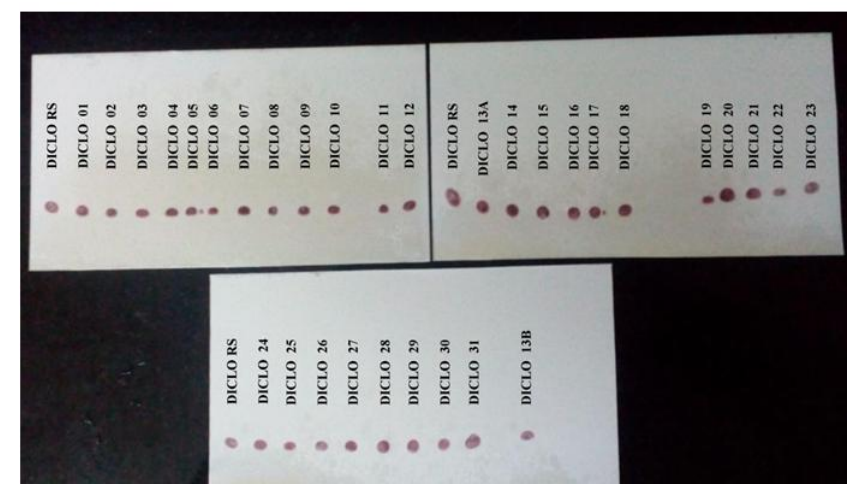

Fig. 1: Diclofenac identification in commercial generic products by TLC. 


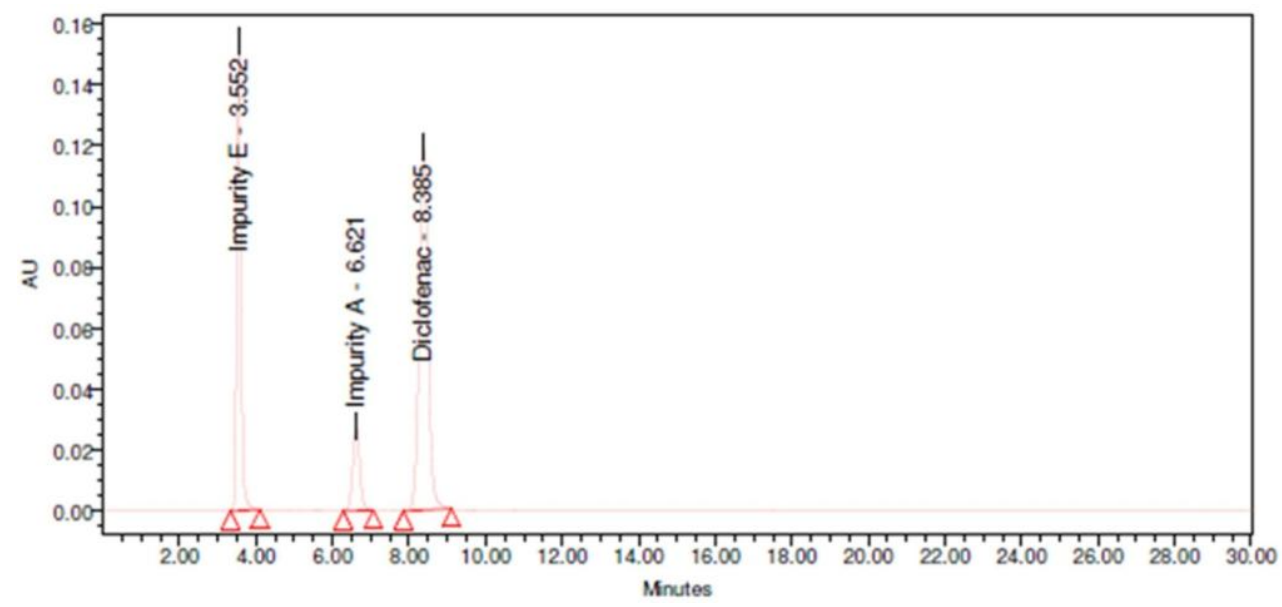

Fig. 2: Auto scale chromatogram of DICLO certified reference standard spiked with its known impurity A and E.

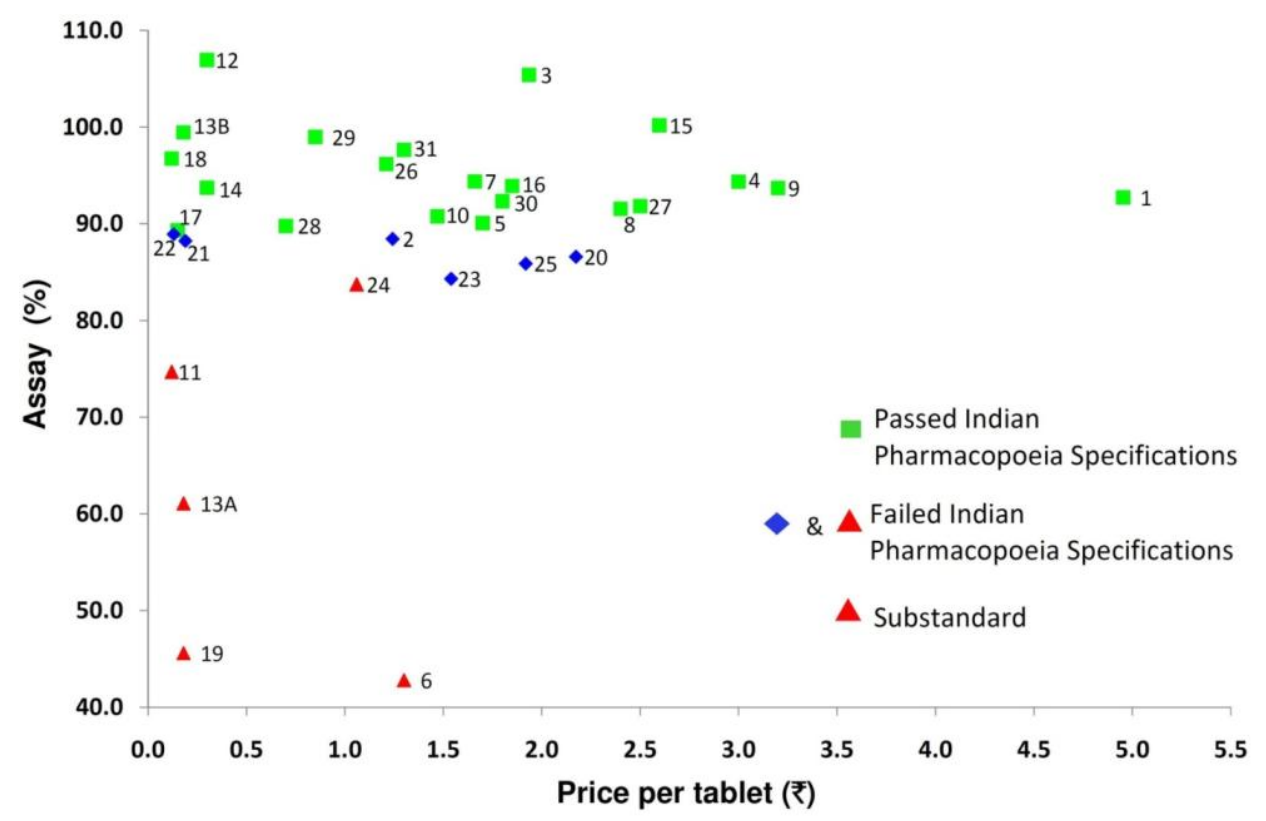

Fig. 3: Comparative price versus assay plot showing quality, out of pharmacopoeia specification and substandard DICLO products.

In filter compatibility analysis, $0.45 \mu \mathrm{m}$ PTFE filter were selected for filtering reference standard and samples. Relative retention time of impurity $\mathrm{E}$, impurity $\mathrm{A}$ and diclofenac was about 3.55, 6.62 and $8.38 \mathrm{~min}$ as shown in Figure 2, and all peaks passed the resolution criterion.

According to the recommended ICH guidelines Q2 (R1) proposed method was validated as shown in Table 1. For linearity the sample area count versus concentration was evaluated by linear least square regression. Comparable slopes (9937) and intercepts $(-72612)$ were obtained. Linearity was shown by the good correlation 0.9997 , between area count and the drug concentration as shown in Table 1. The accuracy results showed recoveries between $99.0 \%$ and $101.7 \%$. The method precision and system precision were determined which show 0.27 and $0.94 \%$ RSD respectively. The robustness results signify that the peak area was not significantly affected by changing the flow rate by $\pm 10 \%$, column oven temperature by $\pm 5^{\circ} \mathrm{C}, 10 \%$ relative change in minor component of the mobile phase and changing the wavelength by $\pm 5 \mathrm{~nm}$, as shown in Table 1 .

It was an exploratory pilot scale research to investigate the quality of drug products in the Indian market. Out of total 32 products, $34.37 \%$ failed to pass the pharmacopoeia specification including $15.62 \%$ substandard quality products as shown in Table 2. The potential consequence of such under-dose medications is a matter of concern to the regulatory authorities. These differences may affect the therapeutic effectiveness of products and trust on health system.

A possible explanation for existence of substandard medicines in the market may likely because of negligence in manufacturing, non conformance to good manufacturing practice (CDSCO, 2008) or may be to gain more profit by the manufacturer without knowing the negative consequences of this poor quality like loss of trust on medical practitioners, loss of trust on health system and increased burden on patient. It is noteworthy that not 
only the different products have different assay result; but two batches of same product can have varied results. For example DICLO-13A found to be substandard while DICLO-13B passed the test as shown in Table 2.

All products were procured without prescription and this calamity signifies that how Drug and Cosmetic Act and Rules are misapplying. Medicine seller and buyer both are considering it as a commodity. Medicine should be dispense only as per the rules and guidelines(Indian Pharmaceutical Association, 2002). Medicines are quite complex molecules which may cause morbidity and mortality if use without medical practitioners or pharmacists instructions. Thus good pharmacy practice is highly demanded.

Table 1: Validation of developed HPLC method for diclofenac sodium.

\begin{tabular}{|c|c|}
\hline Validation Parameters & Value \\
\hline \multicolumn{2}{|l|}{ System Suitability } \\
\hline Mean Peak Area & 1938427 \\
\hline Retention Time & 8.3 \\
\hline Tailing Factor & 0.94 \\
\hline Capacity Factor & 7.42 \\
\hline Theoretical Plates & 5542 \\
\hline \multicolumn{2}{|l|}{ Specificity } \\
\hline Sample Spiked with Placebo & $\begin{array}{l}\text { purity angle }(0.027)<\text { purity } \\
\text { threshold }(0.257)\end{array}$ \\
\hline Difference \% of Control and & -1.5 \\
\hline \multicolumn{2}{|l|}{ Spiked Sample(with Impurity) } \\
\hline \multicolumn{2}{|l|}{ Linearity } \\
\hline Correlation Coefficient & 0.9997 \\
\hline Regression Coefficient & 0.9994 \\
\hline Slope & 9937 \\
\hline Intercept & -72612 \\
\hline \multicolumn{2}{|l|}{ Precision (\% RSD) } \\
\hline System Precision & 0.27 \\
\hline Method Precision & 0.95 \\
\hline \multicolumn{2}{|l|}{ Accuracy (\% Recovery) } \\
\hline At $70 \%$ level & $99.0-99.43$ \\
\hline At $100 \%$ level & $101.30-101.70$ \\
\hline At $130 \%$ level & $100.38-100.84$ \\
\hline Overall \% Recovery & 100.46 \\
\hline Overall \% RSD & 0.99 \\
\hline \multicolumn{2}{|l|}{ SIAS Standard at $25^{\circ} \mathrm{C}$ for 24 hours } \\
\hline \multirow{2}{*}{\multicolumn{2}{|c|}{ SIAS Sample at $25^{\circ} \mathrm{C}$ for 24 hours }} \\
\hline & \\
\hline Cumulative \% RSD & 0.88 \\
\hline Assay $\%$ & $100.3-102.1$ \\
\hline \multicolumn{2}{|l|}{ Robustness } \\
\hline \multicolumn{2}{|l|}{ For Standard } \\
\hline \multicolumn{2}{|l|}{$\begin{array}{l}\text { System Suitability } \\
\text { (under modified conditions) }\end{array}$} \\
\hline Theoretical plates & $>4000$ \\
\hline Tailing factor & $<2$ \\
\hline \% RSD( five injections) & $<2$ \\
\hline \multicolumn{2}{|l|}{ For Sample (\% RSD) } \\
\hline Control & 0.23 \\
\hline Flow Minus & 0.38 \\
\hline Flow Plus & 0.35 \\
\hline Temperature Minus & 0.4 \\
\hline Temperature Plus & 0.2 \\
\hline Minor Component Minus & 0.50 \\
\hline Minor Component Plus & 0.26 \\
\hline Wavelength Minus & 0.21 \\
\hline Wavelength Plus & 0.63 \\
\hline
\end{tabular}

Table 2: Diclofenac generic products assay and price.

\begin{tabular}{|c|c|c|c|c|c|c|}
\hline 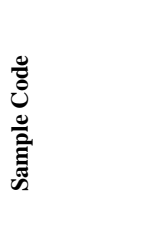 & 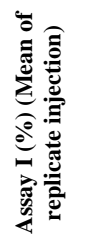 & 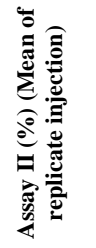 & 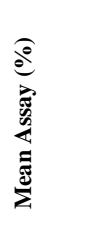 & 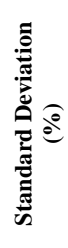 & 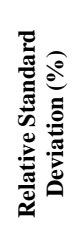 & 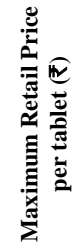 \\
\hline DICLO-01 & 92.35 & 93.10 & 92.73 & 0.53 & 0.57 & 4.95 \\
\hline DICLO-02 & 88.41 & 88.47 & 88.44 & 0.04 & 0.05 & 1.24 \\
\hline DICLO-03 & 105.37 & 105.40 & 105.39 & 0.02 & 0.02 & 1.94 \\
\hline DICLO-04 & 94.07 & 94.63 & 94.35 & 0.40 & 0.42 & 3.00 \\
\hline DICLO-05 & 90.52 & 89.62 & 90.07 & 0.64 & 0.71 & 1.70 \\
\hline DICLO-06 & 43.04 & 42.57 & 42.81 & 0.33 & 0.78 & 1.30 \\
\hline DICLO-07 & 94.91 & 93.84 & 94.38 & 0.76 & 0.8 & 1.66 \\
\hline DICLO-08 & 91.67 & 91.42 & 91.55 & 0.18 & 0.19 & 2.40 \\
\hline DICLO-09 & 93.28 & 94.10 & 93.69 & 0.58 & 0.62 & 3.20 \\
\hline DICLO-10 & 90.39 & 91.14 & 90.77 & 0.53 & 0.58 & 1.47 \\
\hline DICLO-11 & 75.19 & 74.20 & 74.70 & 0.70 & 0.94 & 0.12 \\
\hline DICLO-12 & 106.72 & 107.14 & 106.93 & 0.30 & 0.28 & 0.30 \\
\hline DICLO-13A* & 61.35 & 60.80 & 61.08 & 0.39 & 0.64 & 0.18 \\
\hline DICLO-13B ${ }^{*}$ & 99.18 & 99.71 & 99.45 & 0.37 & 0.38 & 0.18 \\
\hline DICLO-14 & 93.38 & 94.08 & 93.73 & 0.49 & 0.53 & 0.30 \\
\hline DICLO-15 & 100.24 & 100.11 & 100.18 & 0.09 & 0.09 & 2.60 \\
\hline DICLO-16 & 93.94 & 93.88 & 93.91 & 0.04 & 0.05 & 1.85 \\
\hline DICLO-17 & 89.41 & 89.22 & 89.32 & 0.13 & 0.15 & 0.15 \\
\hline DICLO-18 & 96.39 & 97.08 & 96.74 & 0.49 & 0.5 & 0.12 \\
\hline DICLO-19 & 45.60 & 45.64 & 45.62 & 0.03 & 0.06 & 0.18 \\
\hline DICLO-20 & 87.51 & 85.69 & 86.60 & 1.29 & 1.49 & 2.17 \\
\hline DICLO-21 & 88.26 & 88.19 & 88.23 & 0.05 & 0.06 & 0.19 \\
\hline DICLO-22 & 89.13 & 88.71 & 88.92 & 0.30 & 0.33 & 0.13 \\
\hline DICLO-23 & 83.84 & 84.77 & 84.31 & 0.66 & 0.78 & 1.54 \\
\hline DICLO-24 & 83.67 & 83.80 & 83.74 & 0.09 & 0.11 & 1.06 \\
\hline DICLO-25 & 85.67 & 86.11 & 85.89 & 0.31 & 0.36 & 1.92 \\
\hline DICLO-26 & 95.89 & 96.46 & 96.18 & 0.40 & 0.42 & 1.21 \\
\hline DICLO-27 & 91.31 & 92.33 & 91.82 & 0.72 & 0.79 & 2.50 \\
\hline DICLO-28 & 89.67 & 89.89 & 89.78 & 0.16 & 0.17 & 0.70 \\
\hline DICLO-29 & 98.90 & 99.04 & 98.97 & 0.10 & 0.1 & 0.85 \\
\hline DICLO-30 & 92.44 & 92.23 & 92.34 & 0.15 & 0.16 & 1.80 \\
\hline DICLO-31 ${ }^{\#}$ & 97.38 & 97.89 & 97.64 & 0.36 & 0.37 & 1.30 \\
\hline
\end{tabular}

"Two batches, ${ }^{\#} 100 \mathrm{mg}$ dose

The intended study not only identified and quantified DICLO content in different marketed generic brands and local generics but also their relative significance with the cost. As shown in Table 2, DICLO-18 of 0.12 rupee (₹) per tablet passed the assay while at the same price another generic product DICLO11 failed in the test. On the other hand, products labeled with high price like DICLO-06, DICLO-23, DICLO-20 and DICLO-25 were failed in the assay; while DICLO-01, DICLO-04, DICLO-15 and DICLO-16 were passed the evaluation. High severity of underlying situation, as indicated by the results was not significantly related to low cost only as show in Table 3. After demonstrating Fisher's exact test, a two tailed p-value 0.432 showed no significant difference between price and assay value. Therefore, products tagged with high price do not guarantee the good quality and product of low price do not ensure poor quality as shown in Figure 3. It indicates poor quality products exist in the market irrespective of the price and these substandard products range from low price to high price. Further investigations on other category of drugs are necessary to address the concern for quality and affordability of medicines in India. 
Table 3: Price wise distribution of passed and failed DICLO products.

\begin{tabular}{ccc}
\hline $\begin{array}{c}\text { Maximum retail price per } \\
\text { tablet }(₹)\end{array}$ & $\begin{array}{c}\text { No. of products } \\
\text { failed }\end{array}$ & $\begin{array}{c}\text { No. of products } \\
\text { passed }\end{array}$ \\
\hline $0.1-0.5$ & 5 & 5 \\
$>0.5-1$ & - & 2 \\
$>1-2$ & 5 & 8 \\
$>2-3$ & 1 & 3 \\
$>3-4$ & - & 2 \\
$>4-5$ & - & 1 \\
\hline
\end{tabular}

In general, these outcomes highlight the assorted nature of poor quality medication issues that have critical consequences for public health. Such issue should be undertaken by the pharmaceutical researchers or academicians and concerned regulatory agencies, medical practitioners and consumer as well. The Indian government, national regulatory authority and state regulatory authorities need to be very stringent in complying with quality assurance and quality control. Authorities has to review and implement the already recommended interventions by Mashelkar Committee Report(Government of India, 2003). Additional efforts are required to enhance the current manufacturing practices along with the process involved in registration of drugs to control the flow of impoverished medicines in the market.

This work additionally accentuates the requirement for productive oversight of pharmaceutical products, with legitimate observing of manufacturers and their distribution systems to bring down the danger for public being exposed to products of low quality, low safety and low efficacy.

\section{CONCLUSION}

An HPLC assay method has been developed and validated for diclofenac sodium generic market products. The assay method has been validated to be specific, linear $(r=0.9997)$, accurate (recovery 99.0-101.7\%), precise (method precision $\% \mathrm{RSD}=1.39$ and system precision $\% \mathrm{RSD}=0.91)$ and robust. Proposed method can be used for future evaluation of diclofenac sodium tablets.

From the result of this study it is evident that there is a high predominance of low quality DICLO products in northern India and it may be due to non harmonized regulatory system which makes it a challenge to quantify the prevalence of poor quality medicines across the country. Thus there is urgent requirement of large scale study for sufficient data to estimate the true extent of poor quality medicines. Our study aim was not to defame any faulty product or company. It was only directed to publicize maximum awareness to the consumers, pharmacists, medical practitioners and drug regulatory authorities about extent of the problem. This quality assessment of diclofenac products may be regarded as an initiating step for further evaluation of such products or other marketed drug products for the patient safety. Besides affordability and non affordability issue; ambiguous quality of generics tends to cause huge loss to consumers, therefore medicine regulations, policies, practices and research are required to be patient centric. Under urgency it is required to focus on controlling the availability of substandard drugs in the market that are produced as a result of the poor manufacturing and quality-control practices or deliberately falsified drugs. Among the primary challenges; first is to improvise the product quality by enforcement of good manufacturing practice rules and second is regulatory authorities must harmonized and confront in order to make some feasible interventions for improving this crude situation.

\section{CONFLICT OF INTEREST}

The authors declare that they have no conflict of interest.

\section{REFERENCES}

Bate R. 2012. The Deadly World of Falsified and Sub-Standard Medicine. Economic Affairs (Vol. 32). Washington, DC: AEI Press.

Bate R, Tren R, Mooney L, Hess K, Mitra B, Debroy B, Attaran A. Pilot study of essential drug quality in two major cities in India. PLoS ONE, 2009; 4(6), e6003.

Cameron A, Ewen M, Ross-Degnan D, Ball D, Laing R. Medicine prices, availability, and affordability in 36 developing and middle-income countries: a secondary analysis. The Lancet, 2009; 373(9659), 240-249.

CDSCO. 2008. Guidelines for taking action on samples of drug delclared spurious or not of standard quality in the light of enhanced penalties under Drug and Cosmetic (Amendment) Act, 2008. New Delhi. Available at: http://www.cdsco.nic.in/writereaddata/DCC Guidelines on NSQ Drugs.pdf. [Accessed on 10 January 2014]

Chan FK, Hung LC, Suen BY, Wong VW, Hui AJ, Wu JC, Leung WK, Lee YT, To KF, Chung SC, Sung JJ. Celecoxib versus diclofenac plus omeprazole in high-risk arthritis patients: Results of a randomized double-blind trial. Gastroenterology, 2004; 127(4), 10381043.

Drugscontrol.org. 2014. List of Substandard Drugs. Available at: http://www.drugscontrol.org/substandard_drugs2014.asp. [Accessed on 18 November 2014]

Dugowson CE, Gnanashanmugam P. Nonsteroidal AntiInflammatory Drugs. Physical Medicine and Rehabilitation Clinics of North America, 2006; 17(2), 347-354.

Government of India. 2003. A comprehensive examination of drug regulatory issues, including the problem of spurious drug. New Delhi. Available at: http://cdsco.nic.in $/ \mathrm{html} / \mathrm{html} /$ Final Report mashelkar.pdf. [Accessed on 09 January 2014]

Government of India. 2005. Schedule H-Prescription Drugs. In Drug and cosmetic act and rules (pp. 364-366). New Delhi: Government of India. Available at: http://www.indianmedicine.nic.in/writereaddata/ mainlinkFile/File222.pdf. [Accessed on 09 February 2014]

Green MD. 2015. Perspectives: Pharmaceutical Quality and Counterfeit Drugs. Centers for Disease Control and Prevention. Accessed on July 11, 2015, from http://wwwnc.cdc.gov/travel/yellowbook/2016/thepre-travel-consultation/perspectives-pharmaceutical-quality-counterfeitdrugs. [Accessed on 18 August 2015]

Grover A, Citro B. India: Access to affordable drugs and the right to health. The Lancet, 2011; 377(9770), 976-977.

Heyman ML, Williams RL. Ensuring global access to quality medicines: Role of the US pharmacopeia. Journal of Pharmaceutical Sciences, 2011; 100(4), 1280-1287.

ICH. 2005. Validation of a analytical Procedures: text and methodology Q2(R1). International Conference on Harmonisation of Technical Requirements for Registration of Pharmaceuticals for Human Use (ICH) (Vol. 1994). Available at: http://www.ich.org/fileadmin/ Public_Web_Site/ICH_Products/Guidelines/Quality/Q2_R1/Step4/Q2_R1 __Guideline.pdf. [Accessed on 10 January 2014]

Indian Pharmaceutical Association. 2002. Good Pharmacy Practice Guidelines. Mumbai. Available at: http://www.ipapharma.org/ html/GPP_Guidelines_IPA2002.pdf. [Accessed on 05 December 2014] 
International Medical Products Anti-Counterfeiting Taskforce (IMPACT). (2008). Counterfeit Drugs Kill! International Medical Products Anti-Counterfeiting Taskforce (IMPACT). Available at: http://scholar.google.com/scholar?hl=enandbtnG=Searchandq=intitle:Cou nterfeit+Drugs+Kill!\#5. [Accessed on 05 July 2014]

IP. 2010. Diclofenac Tablets Monograph. In Indian Pharmacopoeia. The Indian Pharmacopoeia Commission.

Johnston A, Holt DW. Substandard drugs: A potential crisis for public health. British Journal of Clinical Pharmacology, 2014; 78(2), 218 243.

Khan AN, Khar RK. Current Scenario of Spurious and Substandard Medicines in India: A Systematic Review. Indian Journal of Pharmaceutical Sciences, 2015; 77(1), 2-7. Available at: http://www.ijpsonline.com/temp/IndianJPharmSci7712-

341588_005655.pdf. [Accessed on 15 March 2015]

King DR, Kanavos P. Encouraging the use of generic medicines: implications for transition economies. Croatian Medical Journal, 2002; 43(4), 462-469.

Martin LJ. 2011. The 10 Most Prescribed Drugs. WebMD. Available at: http://www.webmd.com/news/20110420/the-10-mostprescribed-drugs. [Accessed on 11 January 2015]

McGettigan P, Henry D. Use of Non-Steroidal AntiInflammatory Drugs That Elevate Cardiovascular Risk: An Examination of Sales and Essential Medicines Lists in Low-, Middle and High-Income Countries. PLoS Medicine, 2013; 10(2), e1001388.

Newton PN, Green MD, Fernández FM. Impact of poor-quality medicines in the "developing" world. Trends in Pharmacological Sciences, 2010; 31(3), 99-101.

Nsimba SE. Problems associated with substandard and counterfeit drugs in developing countries: a review article on global implications of counterfeit drugs in the era of antiretroviral (ARVs) drugs in a free market economy. East African Journal of Public Health, 2008; 5(3), 205-210.

PSM. 2010. Proposed methodology to conduct a study on the Extent of spurious drugs in the supply chain of Indian market. India. Available at: http://www.safemedicinesindia.in/pdf/Methodology.pdf. [Accessed on 25 June 2014]

PSM. 2013. Counterfeit Drug Incident Encyclopedia. Partnership for Safe Medicines. Accessed on January 12, 2015, from http://www.safemedicines.org/counterfeit-drug-incident-

encyclopedia.html. [Accessed on 28 June 2014]

Rostom A, Dube C, Wells G, Tugwell P, Welch V, Jolicoeur E, McGowan J. Prevention of NSAID-induced gastroduodenal ulcers. Cochrane Database of Systematic Reviews (Online), 2002; (4), CD002296.
Sheth PD, Reddy MVSP, Regal B, Kaushal M, Sen K, Narayana DBA. 2007. Extent of Spurious ( Counterfeit ) Medicines in India. SEAEPharm Forum, Apothecaries Foundation and Delhi Pharmaceutical Trust report.

Silverstein FE, Faich G, Goldstein JL, Simon LS, Pincus T, Whelton A, Makuch R, Eisen G, Agarwal NM, Stenson WF, Burr AM, Zhao WW, Kent JD, Lefkowith JB, Verburg KM, Geis, G. S. Gastrointestinal toxicity with celecoxib vs nonsteroidal anti-inflammatory drugs for osteoarthritis and rheumatoid arthritis: the CLASS study: A randomized controlled trial. Celecoxib Long-term Arthritis Safety Study. JAMA: The Journal of the American Medical Association, 2000; 284(10), 1247-1255.

Suleman S, Zeleke G, Deti H, Mekonnen Z, Duchateau L, Levecke B, Vercruysse J, D'Hondt M, Wynendaele E, De Spiegeleer B Quality of Medicines Commonly Used in the Treatment of Soil Transmitted Helminths and Giardia in Ethiopia: A Nationwide Survey. PLoS Neglected Tropical Diseases, 2014; 8(12), e3345.

USP29-NF24. Diclofenac Sodium -Delayed Release Tablets. In United State Pharmacopoeia (p. 683). United State Pharmacopoiea. Available at: http://www.pharmacopeia.cn/v29240/ usp29nf24s0_m24970.html. [Accessed on 25 January 2014]

WHO. General information on counterfeit medicines. World Health Organization. Available at: http://www.who.int/medicines/ services/counterfeit/overview/en/. [Accessed on 16 January 2015]

WHO. 2007. WHO Medicine Strategy: Countries at the core. Geneva. Available at: http://apps.who.int/medicinedocs/pdf/s5416e/ s5416e.pdf. [Accessed on 15 January 2015]

WHO. 2012. Medicines: spurious/falsely-labelled/falsified/ counterfeit (SFFC)medicines. World Health Organization. Available at http://www.who.int/mediacentre/ factsheets/fs275/en/. [Accessed on 15 January 2015].

\section{How to cite this article:}

Khan AN, Khar RK, Udayabanu M. Pilot Study of Quality of Diclofenac Generic Products Using Validated In-House Method: Indian Drug Regulatory Concern. J App Pharm Sci, 2015; 5 (12): $147-153$. 